He went on to set down a non-exhaustive list of cases that might be suitable for an interim faculty, namely:

i. Where the church is unlisted or, exceptionally, where the affected part of a listed church is of no significance or where EH, the CBC or any relevant amenity society has indicated its consent to the works;

ii. Where the church has been subject to repeated thefts or is at significant risk of future theft;

iii. Where the affected area is not visible from the ground and/or forms no part of the historic or aesthetic importance of the church;

iv. Where the damage or risk of damage to the interior of the building is such that immediate intervention is deemed expedient.

The chancellor made clear that each case should be determined on its own merits and encouraged $\mathrm{EH}$ and the $\mathrm{CBC}$ to put in place procedures to deal speedily with cases of genuine emergency. [RA]

doi:10.1017/So956618X12000221

\title{
Re St Mary, Stafford
}

Lichfield Consistory Court: Thomas Dep Ch, November 2011

Reordering - replacement of church door

A faculty was granted for the re-ordering of a Grade I listed church that included the replacement of the main church door, which dated from a restoration of the church by Gilbert Scott in the 1840 . The proposals as a whole were supported by the diocesan advisory committee (DAC), the Church Buildings Council and English Heritage (EH). Objections from the Victorian Society and parishioners were confined to the proposal to remove the door. Applying the Bishopsgate questions, the deputy chancellor held that a case of necessity had been made out: replacement of the door was necessary in terms of mission, including the accessibility of disabled people and those with young children. Although its replacement would adversely affect the character of the church, the proven necessity was such as to outweigh such adverse effect, particularly in the light of the detailed assessment of the proposals by the DAC and EH. A condition was attached to the grant of the faculty requiring that the door be retained and that consideration be given to its being displayed in the church. [Alexander McGregor] 